\title{
GROWTH, LEAF AND STOMATAL TRAITS OF CRABWOOD (Carapa guianensis Aubl.) IN CENTRAL AMAZONIA ${ }^{1}$
}

\author{
Miguel Angelo Branco Camargo² e Ricardo Antonio Marenco ${ }^{2}$
}

\begin{abstract}
Crabwood (Carapa guianensis Aubl.) is a fast growing tree species with many uses among Amazonian local communities. The main objective of this study was to assess the effect of seasonal rainfall pattern on growth rates, and seasonal and diurnal changes in leaf gas exchange and leaf water potential $\left(\Psi_{\mathrm{L}}\right)$ in crabwood. To assess the effect of rainfall seasonality on growth and physiological leaf traits an experiment was conducted in Manaus, AM ( $\left.03^{\circ} 05^{\prime} 30^{\prime \prime} \mathrm{S}, 5^{\circ} 5^{\circ} 9^{\prime} 35^{\prime \prime} \mathrm{S}\right)$. In this experiment, six 6-m tall plants were used to assess photosynthetic traits and $\Psi_{\mathrm{L}}$. In a second experiment the effect of growth irradiance on stomatal density $\left(\mathrm{S}_{\mathrm{D}}\right)$, size $\left(\mathrm{S}_{\mathrm{S}}\right)$ and leaf thickness was assessed in $0.8-\mathrm{m}$ tall saplings. Stomatal conductance $\left(\mathrm{g}_{\mathrm{s}}\right)$ and light-saturated photosynthesis $\left(A_{\max }\right)$ were higher in the wet season, and between 09:00 and 15:00 h. However, no effect of rainfall seasonality was found on $\Psi_{\mathrm{L}}$ and potential photosynthesis ( $\mathrm{CO}_{2}$-saturated). $\Psi_{\mathrm{L}}$ declined from $-0.3 \mathrm{MPa}$ early in the morning to -0.75 MPa after midday. It increased in the afternoon but did not reach full recovery at sunset. Growth rates of crabwood were high, and similar in both seasons ( $\left.2 \mathrm{~mm} \mathrm{month}^{-1}\right)$. Leaf thickness and $S_{D}$ were $19 \%$ and $47 \%$ higher in sun than in shade plants, whereas the opposite was true for $\mathrm{S}_{\mathrm{S}}$. We conclude that $\Psi_{\mathrm{L}}$ greatly affects carbon assimilation of crabwood by reducing $\mathrm{g}_{\mathrm{s}}$ at noon, although this effect is not reflected on growth rates indicating that other factors offset the effect of $\mathrm{g}_{\mathrm{s}}$ on $A_{\max }$.
\end{abstract}

Keywords: Photosynthesis, Stomatal density, Crabwood and Amazonia.

\section{CRESCIMENTO, CARACTERÍSTICAS FOLIARES E ESTOMÁTICAS DE ANDIROBA (Carapa guianensis Aubl.) NA AMAZÔNIA CENTRAL}

\begin{abstract}
Resumo - A andiroba (Carapa guianensis Aubl.) é espécie de crescimento rápido e muito utilizada pelas comunidades da Amazônia. O principal objetivo deste estudo foi determinar o efeito da sazonalidade da chuva na taxa de crescimento, variação diurna das trocas gasosas e potencial hídrico foliar $\Psi_{L}$ em andiroba. Para determinar o efeito sazonal no crescimento e características fisiológicas foliares dessa espécie, um experimento foi realizado em Manaus, $A M\left(03^{\circ} 05^{\prime} 30^{\prime \prime} \mathrm{S}, 59^{\circ} 59^{\prime} 35^{\prime \prime} \mathrm{S}\right)$. Assim, seis plantas ( $6 \mathrm{~m}$ de altura) da espécie foram utilizadas para determinar as suas características fotossintéticas e o $\Psi_{L}$. Em um segundo experimento, o efeito da irradiância na densidade estomática $\left(S_{D}\right)$, tamanho estomático $\left(S_{S}\right)$ e espessura foliar foi determinado em mudas de $0,8 \mathrm{~m}$ de altura. A condutância estomática $\left(g_{s}\right)$ e a fotossíntese em luz saturante $\left(A_{\max }\right)$ foram máximas na estação chuvosa e entre 9 h e $15 \mathrm{~h}$. Entretanto, não houve efeito sazonal no $\Psi_{L}$ e na fotossíntese potencial ( $\mathrm{CO}_{2}$ saturada). $\Psi_{L}$ declinou de-0,3 MPa pela manhã para-0,75 MPa após o meio-dia, aumentando à tarde e não se recuperando completamente ao anoitecer. A taxa de crescimento foi alta e similar nas duas estações do ano (2 mm mês ${ }^{-1}$ ). A espessura foliar e a $S_{D}$ foram $19 \%$ e $47 \%$ maiores nas folhas de sol, sendo o contrário observado quanto ao $S_{S}$. Conclui-se que o $\Psi_{L}$ afeta a assimilação de carbono da andiroba pela redução da $g_{s}$ ao meio-dia, entretanto esse efeito não se reflete na taxa de crescimento, indicando que outros fatores podem compensar o efeito de $g_{s}$ em $A_{\max }$.
\end{abstract}

Palavras-chave: Fotossíntese, Densidade estomática, Andiroba e Amazônia.

\footnotetext{
${ }^{1}$ Recebido em 13.01.2010 e aceito para publicação em 15.11.2011

${ }^{2}$ Instituto Nacional de Pesquisas da Amazônia, INPA, Brasil. E-mail: <branco@inpa.gov.br> e <rmarenco@inpa.gov.br>.
} 


\section{INTRODUCTION}

Crabwood (Carapa guianensis Aubl.) is a fastgrowing, evergreen or deciduous canopy tree (HUC et al., 1994) that can establish in the forest understory (MCHARGUE; HARTSHORN, 1983), and it is often classified as a climax shade-tolerant species (FETCHER et al., 1994). It is native to tropical America and its distribution ranges from the West Indies and Central America to the Guyanas and Brazilian Amazonia. The tree is abundant in the Amazon flood plains in the States of Pará and Amazonas. It is a monoecious and insect-pollinated species, and in the juvenile stage large leaves are produced in the monocaulous, which decrease in size when branching is initiated. Trees of this species often reach over $1 \mathrm{~m}$ in diameter and over $40 \mathrm{~m}$ in height at maturity. It produces a wood of high quality and intermediate wood density, about $0.6 \mathrm{~g} \mathrm{~cm}^{-3}$ (BAUCH; DUNISH, 2000). The timber of crabwood is used for furniture, shingles, millwork, interior trim, boxes, crates, flooring, masts, rafters, sheathing, and other items used in house constructions; thereby, it is one of the most preferred substitute for mahogany (Swietenia macrophylla) in areas where it grows. The bark of this tree contains carapina, an alkaloid presumed to have medical properties, and tannins. Its seeds produce cream-colored and bitter oil (carapa oil) of high acidity which may be employed to cure many ailments including coughs and colds, whooping cough, and skin problems. Young trees grow much faster (10 $\mathrm{mm} \mathrm{yr}^{-1}$ in diameter) than adult trees, which grow at a rate of about $2.5 \mathrm{~mm} \mathrm{yr}^{-1}$ (BAUCH; DUNISCH, 2000; DUNISCH et al., 2002). Despite the importance of its oil and timber there is a dearth of information on leaf traits of crabwood, particularly on the effect of diurnal and seasonal changes in leaf water potential $\left(\Psi_{L}\right)$ on stomatal functioning and photosynthetic characteristics.

Excessive water loss by transpiration as a result of a high leaf to air vapour pressure difference (VPD) may induce stomatal closure (REIS et al., 1988; MARENCO et al., 2006). In isohydric plants, stomata exhibit a strong control of transpiration so that $\Psi_{\mathrm{L}}$ of droughted and watered plants remains constant during the day, whereas in anysohydric plants larger oscillations in $\Psi_{\mathrm{L}}$ can be observed during the day, as a result of low stomatal sensitivity to evaporative demand and leaf water content (TARDIEU; SIMONNEAU, 1998).

Revista Árvore, Viçosa-MG, v.36, n.1, p.07-16, 2012
Understanding how Amazonian rainforest trees, such as crabwood, react to changes in $\Psi_{\mathrm{L}}$ is important because some climate models predict an increase in temperature and a decline in rainfall in decades to come (MYERS, 1988) which may affect plant functioning in an altered environment. Thus, the main objective of this study was to assess the effect of rainfall seasonality on growth rates, leaf gas exchange and $\Psi_{\mathrm{L}}$ in Carapa guianensis. Stomatal characteristics under sun and shade conditions were also examined.

\section{MATERIALS AND METHODS}

\subsection{Study area and plant material}

The study was conducted at the National Institute for Research in the Amazon (Campus V8) in Manaus, AM-Brazil (03 $05^{\prime} 30^{\prime \prime}$ S; 59 59 59 35" W). The city of Manaus has average temperature of $26.7^{\circ} \mathrm{C}$, average rainfall of $2260 \mathrm{~mm}$ (mean of 1961 to 1990, Inmet, 2010), and a relative humidity of $83 \%$. The region has characteristics of humid equatorial climate, with a short mild dry season (July-September, with a rainfall of 50-100 mm per month). The wet season extends from November to May (200-300 mm month $^{-1}$ ), whereas October is a dry-wet transition period. Thus, during most of the year (October to June) precipitation exceeds evaporation. Mean temperature oscillates from $26.1^{\circ} \mathrm{C}$ in January-March to $27.5^{\circ} \mathrm{C}$ in September-November. Over the year, maximum mean temperatures vary from $30.6^{\circ} \mathrm{C}$ (January-March) to $32.6^{\circ} \mathrm{C}$ (August-November). Minimum mean temperature is $23.3^{\circ} \mathrm{C}$ with little variation over the year. Monthly relative humidity ranges between $75-80 \%$ in the dry season to $81-87 \%$ in the wet season (Inmet, 2010).

We conducted two experiments. In the first experiment, we assessed the effect of diurnal and rainfall seasonality on leaf gas exchange and $\Psi_{\mathrm{L}}$. In the second experiment, we determined the effect of leaf growth irradiance on anatomical leaf traits.

In the first experiment, six open-growth trees of Carapa guianensis Aubl. (Meliaceae) about $6 \mathrm{~m}$ in height and 50-80 mm in diameter were used. Diameter growth (at $1.3 \mathrm{~m}$, breast height) was recorded at monthly intervals between 2006 and 2008. Gas exchange and $\Psi_{L}$ data were collected during four consecutive days in both the dry (August) and wet (January) season of 2008. A double sided step ladder was used to reach canopy leaves for gas exchange measurements. In the

\footnotetext{
Revista Ârvore, Viçosa-MG, v.36, n.1, p.07-16, 2012
} 
second experiment, carried out in 2009, a group of 10 saplings was grown from seeds in $10 \mathrm{~L}$ pots under shade conditions $\left(0.5 \mathrm{~mol} \mathrm{~m}^{-2}\right.$ day $^{-1}$ and about $10 \mu \mathrm{mol} \mathrm{m}^{-2} \mathrm{~s}^{-1}$ at noon). The substrate used for plant growth was soil from a natural forest collected from the first $0.2 \mathrm{~m}$ from the soil surface. It was amended with $5 \mathrm{~g} \mathrm{~kg}^{-1}$ of a slow release fertilizer (Basacote ${ }^{\circledR}$ ). When the plants were 0.8-m tall, a group of five plants was transferred to a full sunlight environment $\left(26 \mathrm{~mol} \mathrm{~m}^{-2}\right.$ day $^{-1}$ and about $1200 \mu \mathrm{mol} \mathrm{m}{ }^{-2} \mathrm{~s}^{-1}$ at midday) for 60 days. At the end of this period, leaf trait data were collected.

\subsection{Gas exchange and water potential measurements (experiment 1)}

Net photosynthetic rate $(A)$ and stomatal conductance $\left(\mathrm{g}_{\mathrm{s}}\right)$ were measured with a portable open gas exchange system fitted with infrared gas analyzer (Li-6400, Li-Cor, Lincoln, NE, USA) and an independent control of $\mathrm{CO}_{2}$ and photosynthetic photon flux density (Q). Data were collected on fully expanded leaves of similar age and appearance at ambient temperature. The effect time of day on $A$ and $\mathrm{g}_{\mathrm{s}}$ was assessed by collecting data at 1-h interval from 06:00 to 18:00 h. When $\mathrm{g}_{\mathrm{s}}$ was higher (09:00-15:00 h) and the system stable (coefficient of variation less than $0.7 \%$ at a $\mathrm{Q}$ of $500 \mu \mathrm{mol} \mathrm{m}{ }^{-2} \mathrm{~s}^{-1}$ in the leaf chamber), $A-\mathrm{C}_{\mathrm{i}}$ and light-response curves $[A(\mathrm{Q})]$ were constructed. The $A-\mathrm{C}_{\mathrm{i}}$ relationship was examined by measuring, $A$ at $380 \mu \mathrm{mol} \mathrm{mol}{ }^{-1}$, then the $\left[\mathrm{CO}_{2}\right]$ was reduced stepwise to $250,200,150,100$, and $50 \mathrm{mmol} \mathrm{mol}^{-1}$, and after that, it was increased to 380, 500, 1000 and $2000 \mu \mathrm{mol} \mathrm{mol}^{-1}$ while illumination in the leaf chamber was kept constant at $1000 \mu \mathrm{mol} \mathrm{m} \mathrm{m}^{-2} \mathrm{~s}^{-1}$. To obtain $A(\mathrm{Q})$ data, photon flux density (Q) was increased to $2000 \mu \mathrm{mol} \mathrm{m}^{-2} \mathrm{~s}^{-1}$ and $A$ values recorded, then light intensity was decreased stepwise. The apparent quantum yield $(\Phi)$ was calculated by using data from the $A(\mathrm{Q})$ response curve at low PFD values $\left(<80 \mu \mathrm{mol} \mathrm{m} \mathrm{m}^{-2} \mathrm{~s}^{-1}\right)$. Stomatal limitation $\left(L_{\mathrm{s}}\right)$ to photosynthesis was calculated as follows (FARQUHAR; SHARKEY, 1982): $L_{\mathrm{s}}=100\left(A_{0}-A\right) / A_{0}$; where, $A_{0}$ is the photosynthetic rate at $380 \mu \mathrm{mol} \mathrm{mol}^{-1}$ when stomatal resistance is zero (i.e. $\mathrm{C}_{\mathrm{i}}=\mathrm{C}_{\mathrm{a}}$ ) and $A$ is the actual photosynthetic rate at a $C_{a}$ value of 380 $\mu \mathrm{mol} \mathrm{mol}{ }^{-1}$ (ambient air). After Jacob and Lawlor (1991), we calculated the mesophyll limitation as: $L_{\mathrm{m}}=100$ $\left(A_{C}-A_{S}\right) / A_{C}$, where $A_{C}$ and $A_{S}$ are $\mathrm{CO}_{2}$-saturated $A$ $\left(\mathrm{C}_{i}>800 \mathrm{~mol} \mathrm{~mol}^{-1}\right)$ of control (wet season) and stressed leaves (dry season), respectively.
Leaf water potential $\left(\Psi_{\mathrm{L}}\right)$ was determined from 07:00 to $18: 00 \mathrm{~h}$ at 1 -h intervals using psycrometric sensors ( $L-51$, Wescor, Utah, USA) connected to a datalogger (Psypro, Wescor, Utah, USA), as previously described (COSTA; MARENCO, 2007). $\Psi_{\mathrm{L}}$ was measured in four leaves per plant and in the same plants used to measure photosynthetic rates. Leaf chlorophyll content was calculated after pigment extraction in 80\%acetone (v/v) and the absorbance of chloroplast solution measured at 645 and $663 \mathrm{~nm}$, as described elsewhere (MARENCO et al., 2009).

\subsection{Stomatal characteristics in sun and shade plants (experiment 2)}

To determine the effect of leaf growth irradiance on stomatal characteristics, particularly stomatal density $\left(\mathrm{S}_{\mathrm{D}}\right)$, stomatal size $\left(\mathrm{S}_{\mathrm{S}}\right.$ or guard cell length) and leaf thickness, a group of five shade-grown saplings was transferred to full sunlight for 60 days. The control was another group of five plants kept under low irradiance $\left(0.5 \mathrm{~mol} \mathrm{~m}^{-2}\right.$ day $\left.^{-1}\right)$. Shade conditions were obtained by growing the plants under a nylon screen and beneath the canopy of adult trees. During daytime hours, temperatures oscillated from 26 to $32{ }^{\circ} \mathrm{C}$ outdoors and from 26 to $30{ }^{\circ} \mathrm{C}$ under shade conditions. Whereas relative humidity ranged between 50 to $91 \%$ in the sunny environment and 72 to $96 \%$ under shading. Stomatal characteristics were determined on fully expanded leaves and developed during the 60-dayirradiance treatment. $S_{D}$ and $S_{S}$ were determined on clear nail polish imprints (HILU; RANDALL, 1984) taken from both sides of the leaf surface, at the widest part of the leaf lamina. Stomata were counted in three leaves per plant under a light microscope (Leica DM500, Leica Microsystems, Wetzlar, Germany). $S_{D}$ was recorded in two $0.45-\mathrm{mm}^{2}$ fields of view per polish imprints of the leaf surface. $\mathrm{S}_{\mathrm{S}}$ was measured in a sample of 20 stomata per leaf at $1000 \mathrm{x}$. To determine $\mathrm{S}_{\mathrm{S}}$, an optical reticle (accuracy of $1 \mu \mathrm{m}$ ) was previously mounted on the eyepiece and calibrated against a micrometer slide (Nachet, Paris, France). The stomatal type was determined after dissociation of the leaf epidermis (a fragment of $100 \mathrm{~mm}^{2}$ ) with a solution of water-free acetic acid (glacial acetic acid) and hydrogen peroxide $(1: 1 \mathrm{v} / \mathrm{v})$ at $60^{\circ} \mathrm{C}$ for $48 \mathrm{~h}$ (KRAUS; ARDUIN, 1997). Images were taken with a digital camera (Canon, Sx100-IS, China) coupled to the microscope. The stomatal type was defined following the criteria of Baranova (1992), by observing the arrangement of the subsidiary or neighbouring cells

Revista Árvore, Viçosa-MG, v.36, n.1, p.07-16, 2012 
immediately adjacent to the stomatal pore. Specific leaf area (SLA) was determined as the area to leaf mass ratio. Leaf area was measured with a portable leaf area meter ( $L i-3050, L i-C o r, N E$, USA), whereas leaf mass was determined by using a standard laboratory balance (0.1 mg precision). Leaf thickness was measured as the transversal leaf section under microscope at 1000x magnification. Besides SLA, the sclerophyll index $\left(\mathrm{S}_{\mathrm{I}}\right.$, half dry mass to leaf area ratio) was also used to assess the effect of irradiance on leaf morphology (RIZZINI, 1976). To assess statistical significance of seasonal rainfall pattern and growth irradiance on variables examined, the Student's test was used. Probability values of less than 0.05 were considered significant. The standard error (SE) was used to compare the effect of time of day on $A_{\max }, g_{s}$ and $\Psi_{L}$.

\section{RESULTS}

Photosynthetic photon flux density (Q) was higher in the dry season than in the rainy season (Figure 1A) because of higher cloudiness in rainy months. Irrespective of season of the year, $A$ and $g_{\mathrm{s}}$ were higher between 09:00 and 15:00 h, indicating that stomata remained closed or partly closed early in the morning and at the end of the afternoon. Regardless of light intensity in the leaf chamber, $\mathrm{g}_{\mathrm{s}}$ followed the same trend as $A$ (Figures 1B-C).

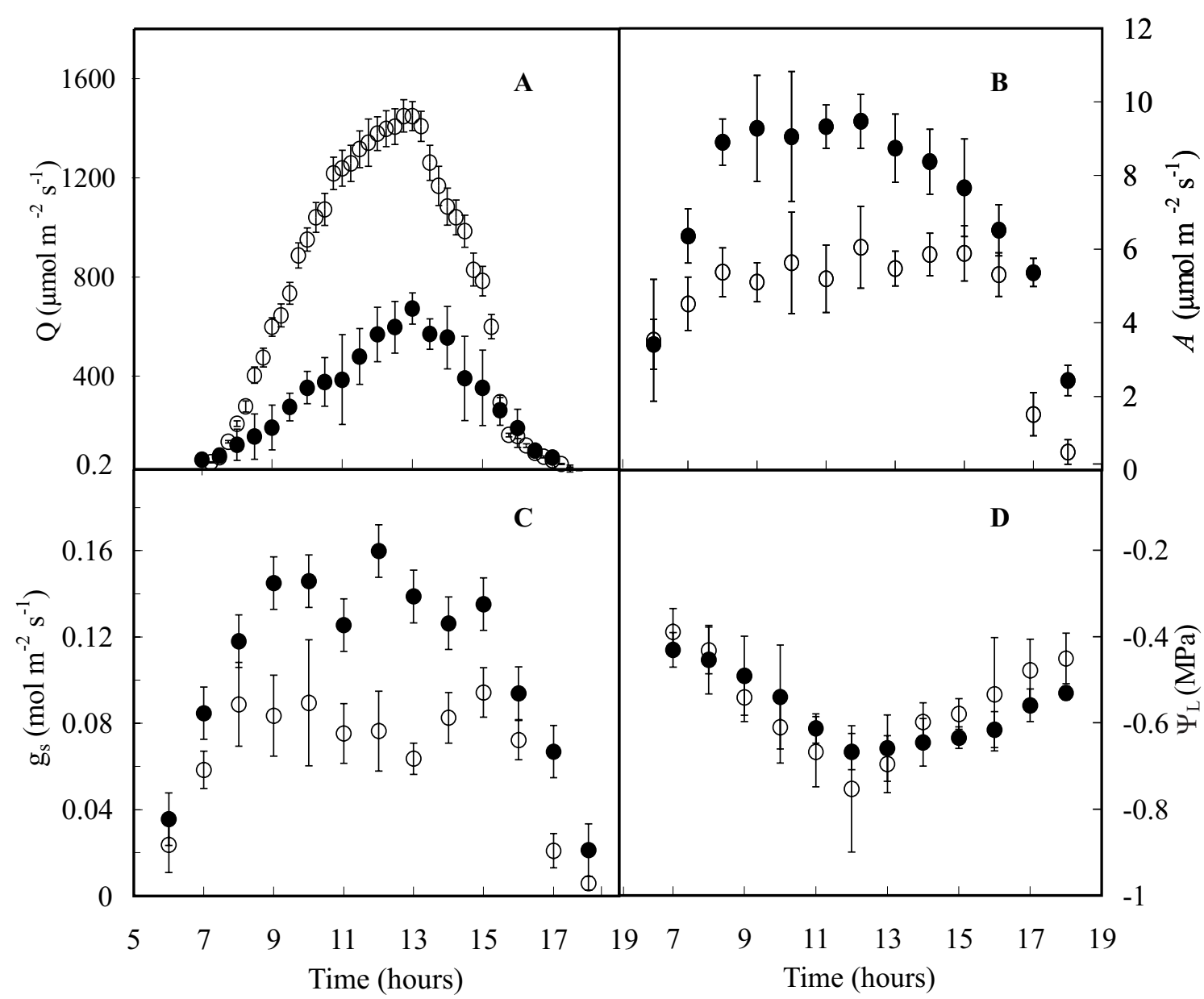

Figure 1 - Photosynthetic photon flux density $(\mathrm{Q}, \mathrm{A})$, photosynthetic rates $(\mathrm{A}, \mathrm{B})$, stomatal conductance $\left(\mathrm{g}_{\mathrm{s}}, \mathrm{C}\right)$ and leaf water potential $\left(\Psi_{L}, D\right)$ in crabwood as a function of time, in the dry season $(O$, open circle) and the rainy season ( closed circle). The bar on each symbol represents the standard error.

Figura 1 - Fluxo de fótons fotossintéticos $(Q, A)$, taxas de fotossíntese $(A, B)$, condutância estomática $\left(g_{s}\right.$, C) e potencial hídrico $\left(\Psi_{L}, D\right)$ de andiroba em função do tempo diurno nas estações seca $(\bigcirc$, círculos abertos) e chuvosa (O , círculos fechados). As barras representam o erro- padrão da média.

Revista Árvore, Viçosa-MG, v.36, n.1, p.07-16, 2012 
$A_{\text {max }}, \mathrm{g}_{\mathrm{s}}$ and the $\mathrm{C}_{\mathrm{i}} / \mathrm{C}_{\mathrm{a}}$ ratio were higher in the wet season than in the dry months of the year (Table 1 ), whereas $\Phi, A_{\text {pot }}$, and the leaf chlorophyll content were not affected by rainfall seasonality. There was a curvilinear and highly significant relationship between $A$ and $\mathrm{g}_{\mathrm{s}}\left(\mathrm{R}^{2}=0.93, \mathrm{p}<0.01\right.$, Figure 2A) confirming that photosynthetic rates $(A)$ are strongly dependent on $g_{s}$. Irrespective of the $C_{i} / C_{a}$ relationship, at low or very low $g_{s}$ the $C_{i} / C_{a}$ ratio tended to increase (Figure $2 B$ ), particularly in the dry months suggesting the occurrence of stomatal patchiness. $L_{\mathrm{m}}$ accounted for about $5 \%$ of carbon uptake limitation, whereas the photosynthetic constraint imposed by $L_{\mathrm{s}}$ ranged from $43 \%$ in the wet to $64 \%$ in the dry season indicating that stomatal functioning was the main factor limiting carbon uptake in crabwood trees (Table 1).

Despite the effect of season of the year on $A_{\text {max }}$, growth in stem diameter was similar in both seasons (around $2 \mathrm{~mm} \mathrm{month}^{-1}$ ) indicating that the apparent reduction in $A_{\max }$ was offset by the high irradiance observed during the dry season, so that carbon gain at the plant level remained almost unchanged. $\Psi_{\mathrm{L}}$ declined from -0.3 MPa early in the morning to about $-0.75 \mathrm{MPa}$ at noon without any significant effect of the season of year (Figure 1D). After midday, $\Psi_{\mathrm{L}}$ increased but it did not reach full recovery at sunset. Stomata were found only on the abaxial surface (hypostomatic leaves). Sun leaves had a higher (90\%) stomatal density $\left(\mathrm{S}_{\mathrm{D}}\right.$ ) than shade leaves (Table 2); on the contrary, stomatal size $\left(\mathrm{S}_{\mathrm{S}}\right)$ was larger in shade leaves (Table 2). Irrespective of growth irradiance stomata were located in epidermal depressions or crypts (Figure 3). The stomata were flanked by three or more subsidiary cells encircling the guard cell pair; anticlinal walls to separate adjacent subsidiary cells radiating from guard cells (laterocytic

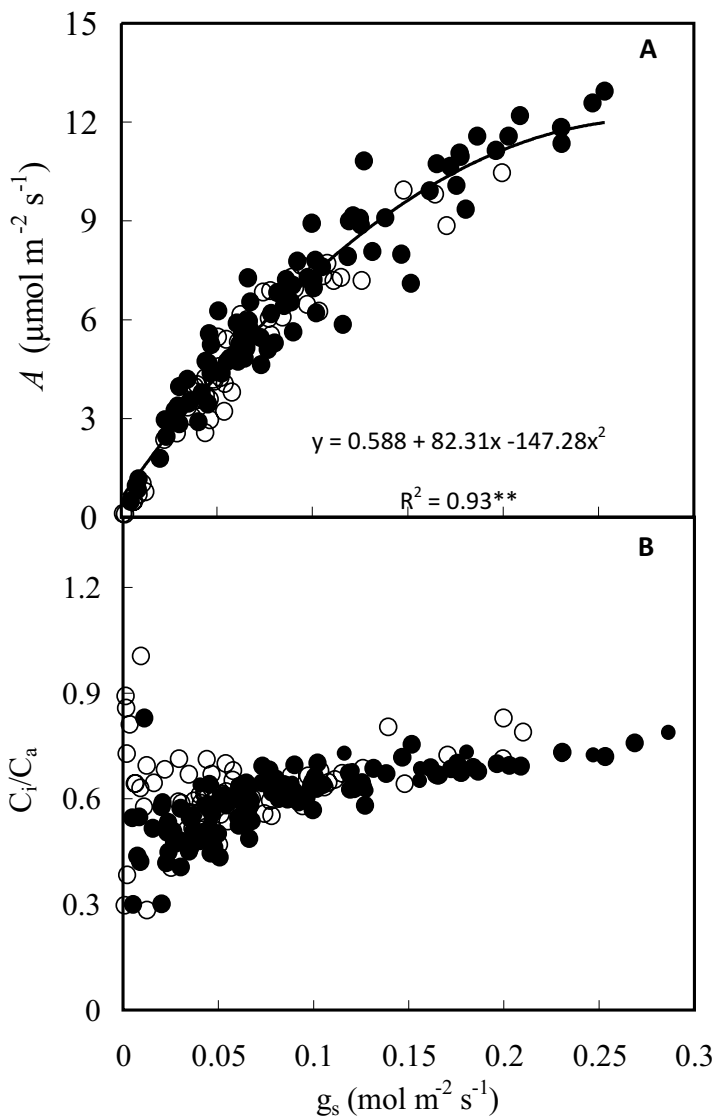

Figure 2 - Photosynthetic rates, $A(\mathrm{~A})$ and the $\mathrm{C}_{\mathrm{i}} / \mathrm{C}_{\mathrm{a}}$ ratio (B) as a function of $g_{s}$ in the dry ( $O$, open circle) and rainy season ( $)$, closed circle). High values of $\mathrm{C}_{\mathrm{i}} / \mathrm{C}_{\mathrm{a}}$ at low $\mathrm{g}_{\mathrm{s}}$ may indicate non-uniform stomatal aperture. ${ }^{* *}$ Significant at $\mathrm{p} \leq 0.01$.

Figura 2 - Taxas fotossintéticas, $A(A)$ e razão $C / C_{a}(B)$ em função de $g_{s}$ nas estações seca ( $O$, círculos abertos) e chuvosa ( , círculos fechados). Altos valores de $C_{i} / C_{a}$ em baixa $g_{s}$ indicam uma não uniforme abertura estomática. $* *$ Significativo com $p \leq 0,01$.

Table 1 - Photosynthetic traits, chlorophyll content and diameter growth rates in crabwood in the dry and wet season (mean \pm standard deviation).

Tabela 1 - Caracteres fotossintéticos, teor de clorofila e crescimento em diâmetro de andiroba nas épocas seca e chuvosa (médias \pm desvio-padrão).

\begin{tabular}{|c|c|c|c|}
\hline Parameters & Dry season & & Wet season \\
\hline$A_{\max }\left(\mu \mathrm{mol} \mathrm{m^{-2 } \mathrm { s } ^ { - 1 } )}\right.$ & $5.6 \pm 0.17 \mathrm{~B}$ & & $8.97 \pm 0.27 \mathrm{~A}$ \\
\hline$g_{s}\left(\mathrm{~mol} \mathrm{~m}^{-2} \mathrm{~s}^{-1}\right)$ & $0.064 \pm 0.05 \mathrm{~B}$ & & $0.107 \pm 0.04 \mathrm{~A}$ \\
\hline$A_{p o t}\left(\mu \mathrm{mol} \mathrm{m}{ }^{-2} \mathrm{~s}^{-1}\right)$ & $20.9 \pm 4 \mathrm{~A}$ & & $21.9 \pm 3.2 \mathrm{~A}$ \\
\hline Apparent quantum yield $\left(\Phi, \mathrm{mol} \mathrm{mol}^{-1}\right)$ & $0.058 \pm 0.001 \mathrm{~A}$ & & $0.062 \pm 0.01 \mathrm{~A}$ \\
\hline $\mathrm{C}_{\mathrm{i}} / \mathrm{C}_{\mathrm{a}}$ relationship (unitless) & $0.48 \pm 0.13 \mathrm{~B}$ & & $0.71 \pm 0.09 \mathrm{~A}$ \\
\hline Stomatal limitation (\%) & $64 \pm 5.6 \mathrm{~A}$ & & $43 \pm 3.7 \mathrm{~B}$ \\
\hline Mesophyll limitation (\%) & & $4.78 \pm 0.81$ & \\
\hline Total chlorophyll content $\left(\mu \mathrm{mol} \mathrm{m} \mathrm{m}^{-2}\right)$ & $357 \pm 27.31 \mathrm{~A}$ & & $406.1 \pm 63.2 \mathrm{~A}$ \\
\hline Diameter growth rate $\left(\mathrm{mm}\right.$ month $\left.^{-1}\right)$ & $1.94 \pm 0.6 \mathrm{~A}$ & & $2.02 \pm 0.45 \mathrm{~A}$ \\
\hline
\end{tabular}


Table 2 - Stomatal density $\left(S_{\mathrm{p}}\right)$, stomatal size $\left(\mathrm{S}_{\mathrm{s}}\right)$, leaf thickness, specific leaf area (SLA) and sclerophyll index $\left(\mathrm{S}_{\mathrm{I}}\right)$ in leaves developed under shade and sunny conditions (mean \pm standard deviation).

Tabela 2 - Densidade estomática $\left(S_{D}\right)$, tamanho estomático $\left(S_{S}\right)$, espessura foliar, área foliar específica (SLA) e índice de esclerofilia $\left(S_{T}\right)$ em folhas desenvolvidas em condições de sombra e sol (médias \pm desvios).

\begin{tabular}{lcc}
\hline Leaf traits & Sun leaves & Shade leaves \\
\hline $\mathrm{S}_{\mathrm{D}}\left(\mathrm{stomata} \mathrm{mm}^{-2}\right)$ & $907 \pm 25 \mathrm{~A}$ & $479 \pm 22 \mathrm{~B}$ \\
$\mathrm{~S}_{\mathrm{S}}(\mu \mathrm{m})$ & $13 \pm 0.26 \mathrm{~B}$ & $15 \pm 0.29 \mathrm{~A}$ \\
Leaf thickness & $0.146 \pm 0.003 \mathrm{~A}$ & $0.118 \pm 0.002 \mathrm{~B}$ \\
$(\mathrm{~mm})$ & & \\
$\mathrm{SLA}\left(\mathrm{m}^{2} \mathrm{~kg}^{-1}\right)$ & $12.25 \pm 1.1 \mathrm{~B}$ & $23.57 \pm 0.1 \mathrm{~A}$ \\
$\mathrm{~S}_{\mathrm{I}}\left(\mathrm{g} \mathrm{cm}^{-2}\right)$ & $0.029 \pm 0.003 \mathrm{~A}$ & $0.012 \pm 0 \mathrm{~B}$ \\
\hline
\end{tabular}

Within rows, means followed by the same letters are not significantly different at $\mathrm{p}=0.05$ as determined by the Student test.

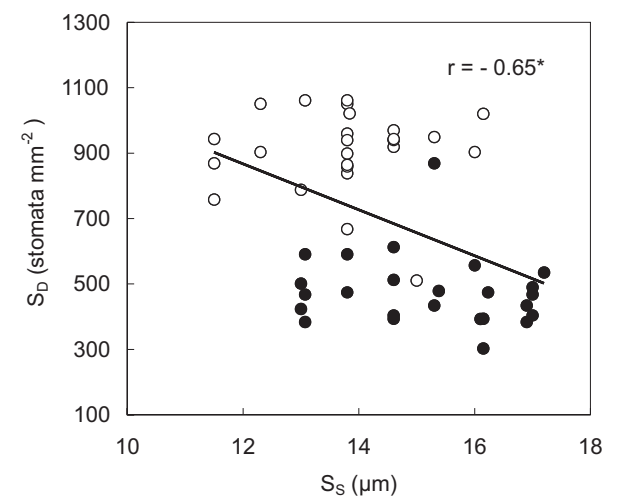

Figure 4 - Correlation between stomatal density $\left(S_{D}\right)$ and stomatal size $\left(\mathrm{S}_{\mathrm{S}}\right)$ in leaves developed under shade ( , closed circle) and sunny conditions $(O$, open circle). * Significant at $\mathrm{p} \leq 0.05$.

Figura 4-Correlação entre densidade estomática $\left(S_{D}\right)$ e tamanho estomático $\left(S_{S}\right)$ em folhas desenvolvidas em condições de sombra (O, círculos fechados) e sol ( $\bigcirc$, círculos abertos). * Significativo com $p \leq 0,05$.

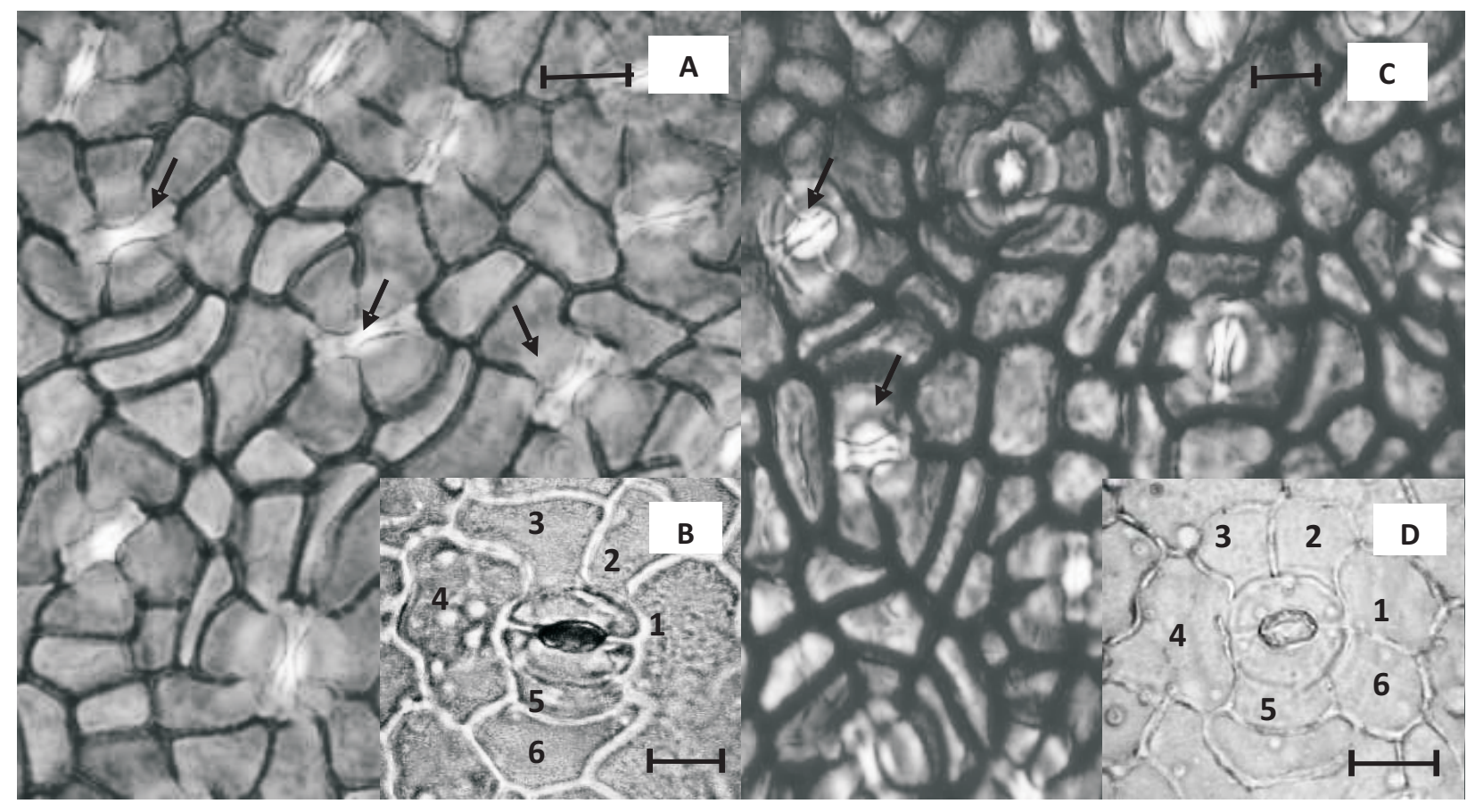

Figure 3 - Laterocytic stomatal complex of crabwood observed abaxially in leaves developed under shade (A, B) and sunny conditions (C, D). The insets (B, D) show the stomatal complex (two guard cells surrounded by six subsidiary cells indicated by numbers). Arrows in the main panel show the stomatal encryptation. The scale bars represent $10 \mu \mathrm{m}$.

Figura 3 - Complexo estomático laterocítico de andiroba observado abaxialmente em folhas desenvolvidas em condições de sombra $(A, B)$ e sol $(C, D)$. Os suplementos $(B, D)$ mostram os complexos estomáticos (duas células-guarda envolvidas por seis células subsidiárias indicadas por números). Setas no painel principal indicam as criptas estomáticas. As escalas (barras) representam $10 \mu \mathrm{m}$.

Revista Árvore, Viçosa-MG, v.36, n.1, p.07-16, 2012 
type; Figure 3). In comparison with sun leaves, $\mathrm{S}_{\mathrm{D}}$, Sclerophyll index $\left(\mathrm{s}_{\mathrm{i}}\right)$ and leaf thickness were $47 \%$, 59\% and 19\% lower in shade leaves. On the other hand, SLA and $S_{S}$ were lower in sun leaves (Table 2). A negative correlation was found between $S_{D}$ and $S_{S}(r=-0.65$, $\mathrm{p} \leq$ 0.05; Figure 4)

\section{DISCUSSION}

The lower irradiance observed in this study in the wet season was not unexpected as a spell of cloudy days is not uncommon in central Amazonia during the rainy season. $A_{\max }$ and $g_{\mathrm{s}}$ showed a diurnal pattern with lower values early in the morning and at the end of the day. Several environmental factors may lead to variations in $\mathrm{g}_{\mathrm{s}}$ during the day, such as light intensity, $\left[\mathrm{CO}_{2}\right]$ and leaf water content (LAWSON et al., 2008). As $\mathrm{CO}_{2}$ concentration in the leaf chamber, boundary layer conductance and light intensity remained constant during photosynthetic measurements we cannot attribute the stomatal closure observed early in the morning and late in the afternoon to variations in these environmental factors. On the other hand, diurnal oscillations in stomatal opening can be explained by changes in leaf water content (Figure 1D). We cannot rule out, however, the effects of circadian rhythms on stomatal functioning as they have been observed in other tree species in the Amazon (DOUGHTY et al., 2006; MAGALHÃES, 2010; MENDES; MARENCO, 2010). $A_{\text {max }}$ differences among seasons most likely reflect the effect of rainfall seasonality on $\mathrm{g}_{\mathrm{s}} \cdot A_{\max }$ was about $41 \%$ of $A_{\text {pot }}$ during the rainy season, but it declined to only $27 \%$ in dry months. The drop in $A_{\max }$ in the dry season can be attributed, at least in part, to a higher stomatal limitation $\left(L_{\mathrm{s}}\right)$ during the dry season (Table 1) when lower $C_{i} / C_{a}$ values were observed. This hypothesis is supported by the fact that $A_{\text {pot }}$ remained almost unaltered between rainfall periods ( $p>0.05$, Table 1$)$. Thus, we conclude that in crabwood, the response of $A$ to leaf water content can be described as Type 1(LAWLOR; CORNIC, 2002), whereby a wild water deficit does not lead to a reduction in $A_{\text {pot }}$.

The low $A_{\max }$ in the dry season could reflect either low water availability in the soil or the effect of a high vapor pressure difference (VPD) on dry months, as stomata often tend to close when VPD is high (COSTA and MARENCO, 2007; EAMUS et al., 2008). The close correlation between $A$ and $g_{\mathrm{s}}$ (Figure 2A, $\mathrm{r}^{2}=0.93$, $\mathrm{p}<0.01$ ) confirms that photosynthetic rates are strongly dependent on $\mathrm{g}_{\mathrm{s}}(\mathrm{p} \leq 0.05)$, as reported by others (CHAVES et al., 2004; MENDES; MARENCO, 2010). Also, it is worth noting that at low or very low $g_{\text {s }}$ the $C_{i} / C_{a}$ ratio was higher than it was expected (Figure 2B). This was attributed to non-uniform stomatal opening, which may cause actual $C_{i}$ values deviate from calculated ones, as reported by Marenco et al. (2006).

Although $A_{\max }$ was lower in the dry season, growth rates remained rather constant along the year (Table 1) which suggests that the detrimental effect of the dry season on $A_{\max }$ is offset by the high irradiance that prevails during the dry season (Figure $1 \mathrm{~A}$ ). Differences in $A_{\max }$ among seasons are not probably related to variation in $\Phi$ or chlorophyll concentrations, as $\Phi$ and leaf chlorophyll content was similar in both seasons. The high growth rate found in this study is a little higher than the crabwood growth rate reported by Dunisch et al. (2002) for a monoculture plantation, a mean of $18.7 \mathrm{~mm} \mathrm{yr}^{-1}$ during the first seven years of development. High growth rate observed in crabwood led us to classify crabwood as an intermediate species in the successional status, rather than shade tolerant as suggested by Fetcher et al. (1994).

In the afternoon, $\Psi_{\mathrm{L}}$ increased but it did not reach full recovery at the end of the day. Diurnal variations in $\Psi_{\mathrm{L}}$ found in this experiment are similar to those observed in other studies (BARKER; PEREZ-SALICRUP, 2000; FISHER et al., 2006). On average, $\Psi_{\mathrm{L}}$ did not decrease below -0.8 MPa, which appears to be the minimum critical $\Psi_{\mathrm{L}}$ for this species, at least under our experimental conditions. Similar diurnal patterns of $\Psi_{\mathrm{L}}$ between rainfall seasons suggest that $\mathrm{g}_{\mathrm{s}}$ had an important role in controlling water loss via transpiration. This is in agreement with results reported by Fisher et al. (2006) for other Amazonian tree species In this experiment, the drop in $\Psi_{L}$ had an effect on both $A_{\max }$ and $g_{\mathrm{s}}$, which was consistently lower in the dry season. The effect of a decline of $\Psi_{\mathrm{L}}$ on $A_{\max }$ was more pronounced in the afternoon, particularly in the dry season, as restrictions in stomatal aperture reduce carbon uptake.

Stomatal density and $\mathrm{S}_{\mathrm{S}}$ found in crabwood leaves are within the range of values reported for other hypostomatous leaves in the Amazon (CAMARGO; MARENCO, 2011). In comparison with shade leaves, under high irradiance (full sunlight) $S_{D}$ was higher and individual stomata were smaller.

Revista Árvore, Viçosa-MG, v.36, n.1, p.07-16, 2012 
This probably occurs because under high irradiance, smaller stomata confer some adaptive advantage to the plant, as they can open and close more rapidly and thereby enhancing water use efficiency, the ratio of photosynthesis to transpiration (HETHERINGTON; WOODWARD, 2003).

Indeed, the increase of $S_{D}$ and leaf thickness with irradiance seems to be a quite common response in several plant species (FAHN; CUTLER, 1992; VOLENIKOVÁ; TICHÁ, 2001; LIMA JUNIOR et al., 2006). As $S_{D}$ is somewhat related to $g_{s}$ and carbon uptake, it has been suggested that high leaf $S_{D}$ may contribute to improve biomass accumulation (AL AFAS et al., 2006). Stomatal encryptation has often been considered a xerophytic trait, as the location of stomata in depression reduces water loss by transpiration. However, it should be noted that sunken stomata also occurs in plants growing in wet and even flooded environments (JORDAN et al., 2008). This makes difficult to indubitably ascribe the presence of crypts to variations in water regime during plant growth. Indeed, it has been suggested that crypts have a role in facilitating $\mathrm{CO}_{2}$ diffusion from abaxial to adaxial palisade cells (HASSIOTOU et al., 2009). Although the correlation between $S_{D}$ and $\mathrm{S}_{\mathrm{S}}$ was significant $(\mathrm{r}=0.65, \mathrm{p}<0.05)$, it seems that encrypted stomata tend to be less responsive to variation in size, due to reduced peristomatal transpiration, perhaps because in comparison with non-sunked stomata, guard cells of encrypted stomata are less prone to suffer dehydration.

Under sunlight, SLA values were 90\% higher than those observed under shading. On the contrary the $\mathrm{S}_{\mathrm{I}}$, an indication of the amount of vascular and sclerenchyma tissue in the leaf, increased by $140 \%$ in sun leaves. Both low SLA and high $\mathrm{S}_{\mathrm{I}}$ values indicate a tendency to xeromorphism (WITKOWSKI; LAMONT, 1991), thereby to improved water use efficiency. In addition, as an inverse relationship between wind speed and SLA has been found (WOODWARD, 1983), it seems that a high proportion of hard sclerenchymatous tissue in a leaf may reduce structural injuries under dry and windy conditions. We concluded that although $A_{\max }$ is higher in the wet than in dry season, monthly growth rate remains unaltered along the year, most likely due an increase in irradiance in the dry season. The tight control of $\mathrm{g}_{\mathrm{s}}$ during the day seems to be responsible for the relative constancy of $\Psi_{L}$ values between seasons, so we classified C. guanensis as an isohydric species.
The high growth rate of crabwood and its capability to adjust leaf traits in response to variation in light environment makes of crabwood a good choice in reforestation programs, where fast growing species are recommended for accelerating forest recovery and successional processes of deforested lands. Besides, such species may also contribute to effectively mitigate the effect of $\mathrm{CO}_{2}$ deposition in the atmosphere. Finally, as a remarkable change in $\mathrm{S}_{\mathrm{I}}$ and other leaf traits were observed in crabwood in response to variations in environment during growth, it can be suggested that this species has a promising potential to acclimate to the altered environment predicted for the near future for most part of the Amazon region.

\section{ACKNOWLEDGMENTS}

This research received financial support from the Fundação de Amparo à Pesquisa do Estado do Amazonas (PIPT-1746-08/FAPEAM) and MCT-INPA (PRJ05-141). The authors thank and CAPES and CNPq for scholarships.

\section{REFERENCES}

AL AFAS, N.; MARRON, N.; CEULEMANS, R. Clonal variation in stomatal characteristics related to biomass production of 12 poplar (Populus) clones in a short rotation coppice culture. Journal of Experimental Botany, v.58, n.1, p.279-286, 2006.

BARANOVA, M. A. Principles of comparative stomatographic studies of flowering plants.

Botanical Review, v.58, n.1, p.49-99, 1992.

BARKER, M. G.; PEREZ-SALICRUP, D. Comparative water relations of mature mahogany (Swietenia macrophylla) trees with and without lianas in a subhumid, seasonally dry forest in Bolivia. Tree Physiology, v.20, n.17, p.1167-1174, 2000.

BAUCH, J.; DUNISCH, O. Comparison of growth dynamics and wood characteristics of plantationgrown and primary forest Carapa guianensis in central Amazonia. IAWA Journal, v.21, n.3, p.321-333, 2000.

CAMARGO, M. A. B.; MARENCO, R.A. Density, size and distribution of stomata in 35 rainforest trees species in Central Amazonia. Acta Amazonica, v.41 no.2, p.205-212, 2011. 
CHAVES, J. H. et al. Seleção precoce de clones de eucalipto para ambientes com disponibilidade diferenciada de água no solo: relações hídricas de plantas em tubetes. Revista Árvore, v.28, n.3, p.333-341, 2004.

COSTA, G. F.; MARENCO, R. A. Fotossíntese, condutância estomática e potencial hídrico foliar em árvores jovens de andiroba (Carapa guianensis). Acta Amazonica, v.37, n.2, p.229-234, 2007.

DOUGHTY, C. E. et al. Circadian rhythms constrain leaf and canopy gas exchange in an amazonian forest. Geophysical Research Letters, v.33, n.1, p. 1- 5, 2006.

DUNISCH, O.; SCHWARZ, T.; NEVES, E. J. M. Nutrient fluxes and growth of Carapa guianensis Aubl. in two plantation systems in the Central Amazon. Forest Ecology and

Management, v.166, n.1, p.55-68, 2002.

EAMUS, D. et al. Comparing model predictions and experimental data for the response of stomatal conductance and guard cell turgor to manipulations of cuticular conductance, leaf-to-air vapour pressure difference and temperature: feedback mechanisms are able to account for all observations. Plant Cell and

Environment, v.31, n.3, p.269-277, 2008.

FAHN, A.; CUTLER, D. Xerophytes. Berlin: Gebrüder Borntraeger, 1992.

FARQUHAR, G. D.; SHARKEY, T. D. Stomatal conductance and photosynthesis. Annual Review Plant Physiology, v.33, p.317-345, 1982.

FETCHER, N.; OBERBAUER, S. F.; CHAZDON, R. L. Physiological ecology of plants. In: MACDADE L.A. et al. (Eds): La selva. Ecology and natural history of a neotropical rain forest. Chicago: The University of Chicago Press, 1994. p.128-141.

FISHER, R.A. et al. Evidence from Amazonian forests is consistent with isohydric control of leaf water potential. Plant, Cell and

Environment, v.29, n.1, p.151-165, 2006.
HASSIOTOU, F. et al. Stomatal crypts may facilitate diffusion of $\mathrm{CO}_{2}$ to adaxial mesophyll cells in thick sclerophylls. Plant Cell and Environment, v.32, n.11, p.1596-1611, 2009.

HETHERINGTON, A. M.; WOODWARD, F. I. The role of stomata in sensing and driving environmental change. Nature, v.424, p.901-908, 2003.

HILU, K. W.; RANDALL, J. L. Convenient method for studying grass leaf epidermis. Taxon, v.33, n.3, p.413-415, 1984.

HUC, R.; FERHI, A.; GUEHL, J. M. Pioneer and late-stage tropical rain-forest tree species (FrenchGuiana) growing under common conditions differ in leaf gas-exchange regulation, carbon-isotope discrimination and leaf water potential. Oecologia, v.99, n.1, p.297-305, 1994.

JACOB, J.; LAWLOR, D. W. Stomatal and mesophyll limitations of photosynthesis in phosphate deficient sunflower, maize, and wheat plants. Journal of Experimental Botany, v.42, n.8, p.1003-1011, 1991.

JORDAN, G. J. et al. The evolutionary relations of sunken, covered, and encrypted stomata to dry habitats in Proteaceae. American Journal of Botany v.95, n.1, p.21-530, 2008.

KRAUS, J. E.; ARDUIN, M. Manual básico de métodos em morfologia vegetal. Seropédica: EDUR, 1997. 163p.

LAWLOR, D. W.; CORNIC, G. Photosynthetic carbon assimilation and associated metabolism in relation to water deficits in higher plants.

Plant Cell and Environment, v.25, n.2, p.275-294. 2002.

LAWSON, T. et al. Reductions in mesophyll and guard cell photosynthesis impact on the control of stomatal responses to light and $\mathrm{CO}_{2}$.

Journal of Experimental Botany, v.59, p.3609-3619, 2008.

LIMA JUNIOR, E. C. et al. Aspectos

fisioanatômicos de plantas jovens de Cupania vernalis Camb. submetidas a diferentes níveis de sombreamento. Revista Árvore, v.30, n.1, p.33-41, 2006.

Revista Árvore, Viçosa-MG, v.36, n.1, p.07-16, 2012 
MAGALHÃES, N. Crescimento e variação diurna da condutância estomática e taxas fotossintéticas de cinco espécies arbóreas da flora amazônica [Growth and diurnal variation of stomatal conductance and photosynthetic rates of five Amazonian tree species]. 2010. 88f. Dissertação (Mestrado em Botanica)) - Instituto Nacional de Pesquisas da Amazonia, Manaus, 2010.

MARENCO, R.A.; ANTEZANA-VERA, S.A.; NASCIMENTO, H. C. S. Relationship between specific leaf area, leaf thickness, leaf water content and SPAD502 readings in six Amazonian tree species.

Photosynthetica, v.47, n.1, p.184-190, 2009.

MARENCO, R. A. et al. Hydraulically based stomatal oscillations and stomatal patchiness in Gossypium hirsutum. Functional Plant Biology, v.33, n.12, p.1103-1113, 2006.

MCHARGUE, L. A.; HARTSHORN, G. S. Seed and seedling ecology of Carapa guianensis.

Turrialba, v.33, n.1, p.399-404, 1983.

MENDES, K. R.; MARENCO, R. A. Leaf traits and gas exchange in saplings of native tree species in the Central Amazonia. Scientia Agricola, v.67, n.6, p. 624-632, 2010.

MYERS, N. Tropical deforestation and climate change. Environmental Conservation, v.15, n.1, p.293-298, 1988.
REIS, G. G.; REIS, M. G. F.; MAESTRI, M. Crescimento e relações hídricas de mudas de Eucalyptus grandis e E. camaldulensis em tubetes sob três regimes de irrigação. Revista Árvore, v.12, n.2, p.183-195, 1988.

\section{RIZZINI, C. T. Tratado de fitogeografia} do Brasil: aspectos ecológicos. São Paulo: Universidade de São Paulo/Hucitec, 1976. 327p.

TARDIEU, F.; SIMONNEAU, T. Variability among species of stomatal control under fluctuating soil water status and evaporative demand - modelling isohydric and anisohydric behaviours. Journal of Experimental Botany, v.49, special issue, p.419-432, 1998.

VOLENIKOVA, M.; TICHA, I. Insertion profiles in stomatal density and sizes in Nicotiana tabacum 1. Plantlets. Biologia Plantarum, v.44, n.2, p.161-165, 2001.

WITKOWSKI, E.T.F.; LAMONT, B. B. Leaf specific mass confounds leaf density and thickness. Oecologia, v. 88, n.4, p.486-493, 1991.

WOODWARD, F. I. The significance of interspecific differences in specific leaf area to the growth of selected herbaceous species from different altitudes. New Phytologist, v.95, n.2, p.313-323, 1983. 